\title{
FIVE NOVEL MUTATIONS IN CYSTINURIA GENES SLC3A1 AND SLC7A9
}

\author{
Popovska-Jankovic $\mathrm{K}^{1}$, Tasic $\mathrm{V}^{2}$, Bogdanovic $\mathrm{R}^{3}$, Miljkovic $\mathrm{P}^{4}$, \\ Baskin $\mathrm{E}^{5}$, Efremov GD ${ }^{1}$, Plaseska-Karanfilska $\mathrm{D}^{1^{*}}$
}

*Corresponding Author: Dijana Plaseska-Karanfilska, Macedonian Academy of Sciences and Arts, Research Center for Genetic Engineering and Biotechnology, 1000 Skopje, Republic of Macedonia; Tel.: +389-2-3235-410; Fax:+389-2-3115-434; E-mail: dijana@manu.edu.mk

\begin{abstract}
Cystinuria is an autosomal recessive disorder that is characterized by impaired transport of cystine, lysine, ornithine and arginine in the proximal renal tubule and epithelial cells of the gastrointestinal tract. The transport of these amino acids is mediated by the $\mathrm{rBAT} / \mathrm{b}^{0,+} \mathrm{AT}$ transporter, the subunits of which are encoded by the genes SLC3A1, located on chromosome 2p16.3-21, and SLC7A9, located on chromosome 19q12-13.1. Based on the urinary cystine excretion patterns of obligate heterozygotes, cystinuria is classified into type I (normal amino acid urinary pattern in heterozygotes) and non type I (a variable degree of urinary hyper excretion of cystine and dibasic amino acids in heterozygotes). On the basis of genetic aspects, cystinuria is classified into type $\mathrm{A}$, is caused by mutations in both alleles of SLC3A1; type B, caused by mutations in both alleles of SLC7A9 and type AB, is caused by one mutation
\end{abstract}

1 Macedonian Academy of Sciences and Arts, Research Center for Genetic Engineering and Biotechnology, Skopje, Republic of Macedonia

2 Faculty of Medicine, Pediatric Clinic, Skopje, Republic of Macedonia

3 Institute of Mother and Child Healthcare, Belgrade, Serbia

4 Clinical Centre, Clinic for Pediatrics, Nis, Serbia

5 Baskent University, Faculty of Medicine, Ankara, Turkey in SLC3A1 and one mutation in SLC7A9. Here we present two novel mutations in the SLC3A1 gene (C242R and L573X), which were found in patients from Serbia, and three in the SLC7A9 gene (G73R, V375I, 1048-1051 delACTC), found in patients from Serbia, Macedonia and Turkey, respectively.

Key words: Cystinuria, Mutation, SLC3A1 gene, SLC7A9 gene

\section{INTRODUCTION}

Cystinuria is an autosomal recessive disorder characterized by impaired transport of cystine, lysine, ornithine, and arginine in the proximal renal tubule and in epithelial cells of the gastrointestinal tract, and resulting in elevated urinary concentrations of these amino acids [1]. Transport of these amino acids is mediated by the $\mathrm{rBAT} / \mathrm{b}^{0,+} \mathrm{AT}$ transporter [2], whose subunits are encoded by the genes SLC3A1, located on chromosome 2p16.3-21 [3], and SLC7A9, located on chromosome 19q12-13.1 $[4,5]$.

Based on the urinary cystine excretion patterns of obligate heterozygotes, cystinuria is classified into type I and non type I [6]. Heterozygotes of type I show a normal amino acid urinary pattern in heterozygotes, whereas those of non type I show a variable degree of urinary hyper excretion of cystine and dibasic amino acids. Mutations in the SLC3A1 
gene cause type I, while mutations in the SLC7A9 gene cause non type I [3,7]. However, an SLC7A9 mutation carrier status was found to be compatible with a normal amino aciduria in $14 \%$ of cases [8]. On the basis of genetic aspects, cystinuria is classified into type A, caused by mutations in both alleles of SLC3A1; type B, caused by mutations in both alleles of SLC7A9 and type AB, caused by one mutation in SLC3A1 and one mutation in SLC7A9 derived from the two parents, respectively [8]. The type $\mathrm{AB}$ is extremely rare [9]. More than 112 mutations in the SLC3A1 gene and 69 in the SLC7A9 gene have been described [10].

\section{MATERIALS AND METHODS}

Patients. We studied 57 cystinuria patients from 45 families with the following ethnic origin: Macedonian (five), Serbian (nine), Albanian (nine), Gypsy (eight), Turkish (nine), Croatian (two), Montenegrin (two) and Egyptian (one). Informed consent was obtained from all patients. In this study we present five families in which novel mutations were found.

Patient CY-3 is of Macedonian origin and was examined as a 9-month-old baby. He had a $12 \mathrm{~mm}$ calculus in the left kidney, which subsequently caused obstruction and the patient underwent pielolithotomy.

Patients CY-8, CY-13 and CY-15 are of Serbian ethnic origin. Patient CY-8 was diagnosed with cystinuria when she was 2 years old. She has had several calculosis and one surgery.

Patient CY-13 experienced his first episode of urolithiasis at the age of 2 years. Due to recurrent urolithiasis, he underwent surgery, and has received extracorporeal shock wave lithotripsy several times.

Patient CY-15 was diagnosed with a calculi in the left kidney when he was 1-year-old. Since then he has undergone two surgeries due to urolithiasis.

Patient CY-36 is of Turkish ethnic origin. Ultrasonographic analysis of the kidneys showed a minimal pelvi-calexeal dilatation and lithiasis of the right kidney.

Methods. The diagnosis of cystinuric patients was based on positive sodium nitroprusside test and amino acid analysis (Beckman 6300 Amino Acid Analyzer; Beckman Coulter Inc., Fullerton, CA,
USA). The patients were classified on the basis of their and their parent's urinary cystine and dibasic amino acid excretion [8]. Genomic DNA was isolated from peripheral blood using Proteinase K-SDS digestion, followed by phenol-chloroform extraction, and ethanol precipitation.

Genomic DNA from all patients was amplified by polymerase chain reaction (PCR), using intron-derived oligonucleotides for each exon in the SLC7A9 [11] and SLC3A1 genes [12]. The mutational screening of the probands was performed by direct sequencing on an ABI PRISM ${ }^{\mathrm{TM}} 310$ Genetic Analyzer (Applied Biosystems, Foster City, CA, USA) with BigDye ${ }^{\mathrm{TM}}$ Terminator Cycle Sequencing Ready Reaction Kit (Applied Biosystems) and the primers used for PCR. Mutations in the family members were detected with PCR analyses followed by single strand conformational polymorphism (SSCP) (C242R, G73R), restriction fragment length polymorphism (RFLP) (MseI for V375I, ApaI for G105R) and heteroduplex analysis (1048-1051 del ACTC).

\section{RESULTS AND DISCUSSION}

Mutational analyses were carried out on 45 unrelated patients by direct sequencing of the exons of the SLC3A1 and SLC7A9 genes. We identified 17 different mutations, 10 in the SLC3A1 gene (T216M, $\mathrm{C} 242 \mathrm{R}, \mathrm{R} 365 \mathrm{~L}, 1136+2 \mathrm{~T} \rightarrow \mathrm{C}, \mathrm{G} 398 \mathrm{R}, \mathrm{R} 456 \mathrm{C}$, M467T, M467K, S547W, L573X), and seven in the SLC7A9 gene (G73R, G105R, A331V, 10481051del ACTC, V375I, S379R, 1265-1266delTG). The most frequent mutations were T216M (21.6\%) and M467T (14.8\%) in the SLC3A1 gene and G105R (22.7\%) in the SLC7A9 gene (manuscript in preparation).

Here we describe five novel mutations: two in the SLC3A1 gene (one missense and one nonsense) and three in the SLC7A9 gene (two missense and one deletion). A summary of the phenotypes of cystinuria patients with novel mutations, and their relatives is shown in Table 1.

Identification of Novel Mutations in the SLC3A1 Gene. The missense mutation C242R, in exon 3 , involves substitution of $\mathrm{T}$ by $\mathrm{C}$ at nucleotide position 724. It changes the cysteine TGT codon to CGT for arginine (Figure 1A). This is a conserved 
Table 1. Summary of the phenotypes of the cystinuria families with novel mutations.

\begin{tabular}{|c|c|c|c|c|c|c|c|c|c|}
\hline \multirow[t]{2}{*}{$\begin{array}{c}\text { Patient } \\
\text { and } \\
\text { Relatives }\end{array}$} & \multirow[t]{2}{*}{$\begin{array}{l}\text { Ethnic } \\
\text { Origin }\end{array}$} & \multirow[t]{2}{*}{$\begin{array}{l}\text { Sex- } \\
\text { Age }\end{array}$} & \multicolumn{4}{|c|}{$\begin{array}{l}\text { Urinary Amino Acid } \\
\text { Concentration }^{\mathrm{a}}\end{array}$} & \multirow[t]{2}{*}{ Type } & \multicolumn{2}{|c|}{ Mutation } \\
\hline & & & Cys & Orn & Lys & Arg & & SLC3A1 Gene & SLC7A9 Gene \\
\hline $\begin{array}{l}\text { CY-3 } \\
\text { Brother } \\
\text { Mother } \\
\text { Father }\end{array}$ & Macedonia & M-1 & $\begin{array}{c}297.80 \\
22.80 \\
42.90 \\
17.80 \\
\end{array}$ & $\begin{array}{c}69.30 \\
16.80 \\
14.60 \\
4.40 \\
\end{array}$ & $\begin{array}{c}364.60 \\
77.80 \\
109.60 \\
69.20 \\
\end{array}$ & $\begin{array}{c}56.50 \\
3.90 \\
1.90 \\
1.70 \\
\end{array}$ & $\begin{array}{c}\text { type } \mathrm{I} / \text { non type I } \\
\text { non type } \mathrm{I} / \mathrm{N} \\
\text { non type } \mathrm{I} / \mathrm{N} \\
\text { type } \mathrm{I} / \mathrm{N}\end{array}$ & & $\begin{array}{c}\text { G105R/V375I } \\
\text { V375I/- } \\
\text { V375I/- } \\
\text { G105R/- } \\
\end{array}$ \\
\hline $\begin{array}{l}\text { CY-8 } \\
\text { Sister } \\
\text { Mother } \\
\text { Father }\end{array}$ & Serbia & F-12 & $\begin{array}{c}88.36 \\
21.43 \\
18.45 \\
102.84\end{array}$ & $\begin{array}{c}207.39 \\
13.81 \\
15.29 \\
68.38\end{array}$ & $\begin{array}{l}683.00 \\
194.56 \\
157.43 \\
366.41 \\
\end{array}$ & $\begin{array}{c}693.03 \\
7.14 \\
24.46 \\
18.07\end{array}$ & $\begin{array}{c}\text { non type } \mathrm{I} / \text { non type I } \\
\text { non type } \mathrm{I} / \mathrm{N} \\
\text { non type } \mathrm{I} / \mathrm{N} \\
\text { non type } \mathrm{I} / \mathrm{N}\end{array}$ & & $\begin{array}{c}\text { G105R/G73R } \\
\text { G73R/- } \\
\text { G105R/- } \\
\text { G73R/- }\end{array}$ \\
\hline $\begin{array}{l}\text { CY-13 } \\
\text { Mother } \\
\text { Father }\end{array}$ & Serbia & M-20 & $\begin{array}{c}110-32 \\
11.08 \\
5.00\end{array}$ & $\begin{array}{c}171.76 \\
9.06 \\
3.82 \\
\end{array}$ & $\begin{array}{c}282.46 \\
32.94 \\
12.35 \\
\end{array}$ & $\begin{array}{c}303.87 \\
6.46 \\
2.27\end{array}$ & $\begin{array}{c}\text { type I/type I } \\
\text { type I/N } \\
\text { type I/N }\end{array}$ & $\begin{array}{c}\mathrm{C} 242 \mathrm{R} / \mathrm{R} 456 \mathrm{C} \\
\mathrm{R} 456 \mathrm{C} /- \\
\mathrm{C} 242 \mathrm{R} /-\end{array}$ & \\
\hline $\begin{array}{l}\text { CY-15 } \\
\text { Father }\end{array}$ & Serbia & M-16 & $\begin{array}{c}75.02 \\
6.45 \\
\end{array}$ & $\begin{array}{c}158.16 \\
5.24\end{array}$ & $\begin{array}{c}240.00 \\
13.54 \\
\end{array}$ & $\begin{array}{c}364.05 \\
1.0\end{array}$ & $\begin{array}{l}\text { type I/unclassified } \\
\text { type I/N }\end{array}$ & $\begin{array}{c}\mathrm{C} 242 \mathrm{R} / \mathrm{L} 573 \mathrm{X} \\
\mathrm{C} 242 \mathrm{R} /-\end{array}$ & \\
\hline $\begin{array}{l}\text { CY-36 } \\
\text { Mother } \\
\text { Father }\end{array}$ & Turkey & F-9 & $\begin{array}{l}91.33 \\
\\
44.93 \\
20.65\end{array}$ & $\begin{array}{c}290.45 \\
12.13 \\
7.03\end{array}$ & $\begin{array}{l}279.12 \\
264.75 \\
120.09\end{array}$ & $\begin{array}{l}825.08 \\
8.20 \\
6.71\end{array}$ & $\begin{array}{l}\text { non type } \mathrm{I} / \text { non type I } \\
\text { non type } \mathrm{I} / \mathrm{N} \\
\text { non type } \mathrm{I} / \mathrm{N}\end{array}$ & & $\begin{array}{l}\text { 1048-1051delACTC/ } \\
\text { 1048-1051delACTC } \\
\text { 1048-1051delACTC/- } \\
\text { 1048-1051delACTC/- }\end{array}$ \\
\hline
\end{tabular}

${ }^{a}$ Reference values in $\mathrm{mM} / \mathrm{M}$ creatinine: $0.6-20.0$ for cystine, $0.1-5.0$ for ornithine, $0.0-153.0$ for lysine, and 0.9-3.6 for arginine.

A)

Normal: T G G C A T G A C T G T A C C CA T Mutant: T G G CA T GA C C G TA C C CAT

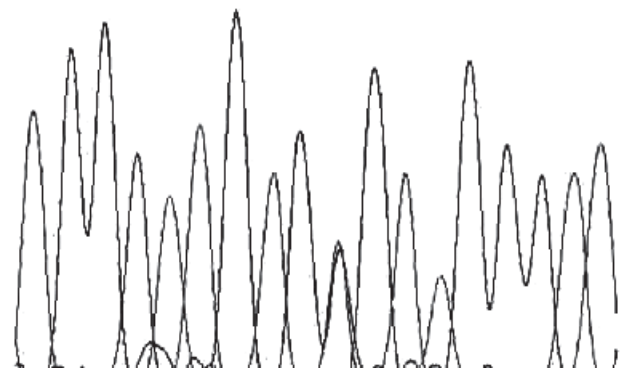

B)

Normal: T T G C CA T T T G A G G A A

Mutant: T T G C CA T T A G A G G A A

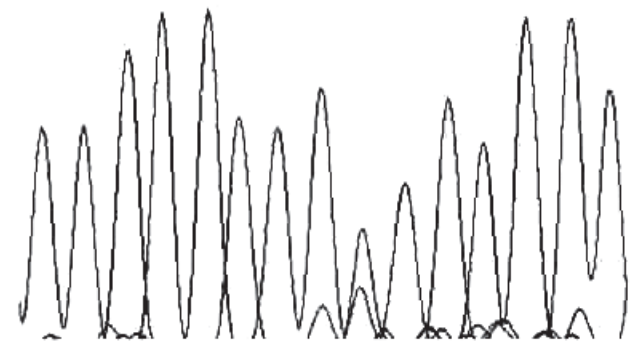

Figure 1. DNA sequence analysis showing the two novel mutations in the SLC3A1 genes. A) C242R and B) L573X.

amino acid residue in a part of a subunit that is located extracellulary, and the effect of the C242R mutation suggest that it may be critical for proper function [13]. This mutation was found in two Serbian patients of whom one was classified as type I cystinuria since his parents exhibited a normal urinary excretion profile (Table 1), and he is a compound heterozygote for $\mathrm{C} 242 \mathrm{R}$ and $\mathrm{R} 456 \mathrm{C}$ (patient CY-13). The R456C mutation involves a conserved residue in a part of the subunit that is located intracellulary [9].

The second patient with C242R (CY-15) was classified as type I/unclassified (Table 1) because the urinary excretion profile of his father was normal, while his mother was unavailable for analysis. The second mutation in patient CY-15 was also a new one, the nonsense L573X mutation in exon 10. This mutation leads to a stop codon instead of a leu- 
cine residue at codon 573 (Figure 1B). The leucine residue is not conserved and the mutation leads to truncation of the subunit by $16.7 \%$, including the fourth transmembrane domain.

Identification of Novel Mutations in the SLC7A9 Gene. The G73R mutation in exon 3 of the SLC7A9 gene was found in a Serbian patient (CY-8). The mutation includes a substitution of $\mathrm{G}$ by $\mathrm{A}$ at nucleotide position 402 (Figure 2A), which leads to the replacement of conserved glycine (GGG) by arginine (AGG). According to the model for the light subunit of this amino acid transporter suggested by Font et al. and the International Cystinuria Consortium [11], glycine at position 73 is a conserved amino acid residue that is located in the second transmembrane domain. The mother, father, and sister were also examined. The patient's urinary excretion profile was non type I/non type I (Table 1).
The patient inherited the G73R mutation from her father, who presented with high values for urinary cystine and dibasic amino acids. CY-8 inherited a G105R mutation from her mother, who also had increased urinary cystine and dibasic amino acids.

The second novel mutation found in the SLC7A9 gene was V375I in exon 11 (Figure 2B) that involves a substitution of $\mathrm{G}$ by $\mathrm{A}$ at position 1123 . This mutation involves the substitution of valine by isoleucine and is located on the boundary between the fifth extracellular loop and tenth transmembrane domain. The patient inherited this mutation from his mother, and a second mutation (G105R) from his father. The urinary amino acid profile of patient $\mathrm{CY}$ 3 was type I/non type I, since the mother exhibited elevated levels of cystine and ornithine, consistent with non type I cystinuria, while the father showed normal urinary amino acid levels, consistent with

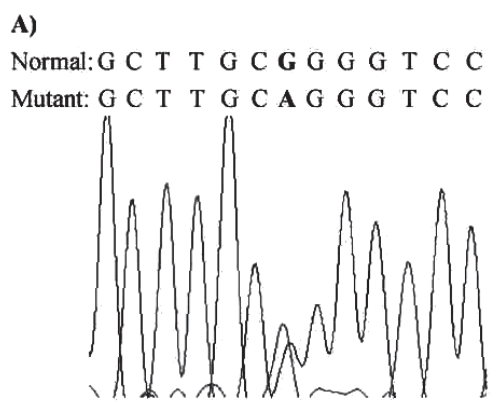

B)

Normal: $\mathrm{T}$ C G T T A G T C A A T T A

Mutant: $\mathrm{T}$ C G T T A A T C A A T T A

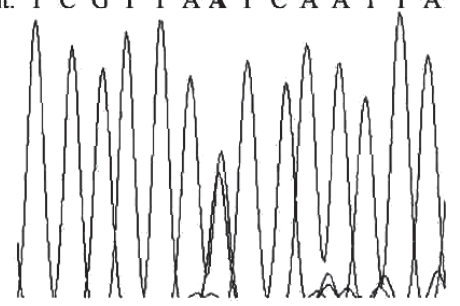

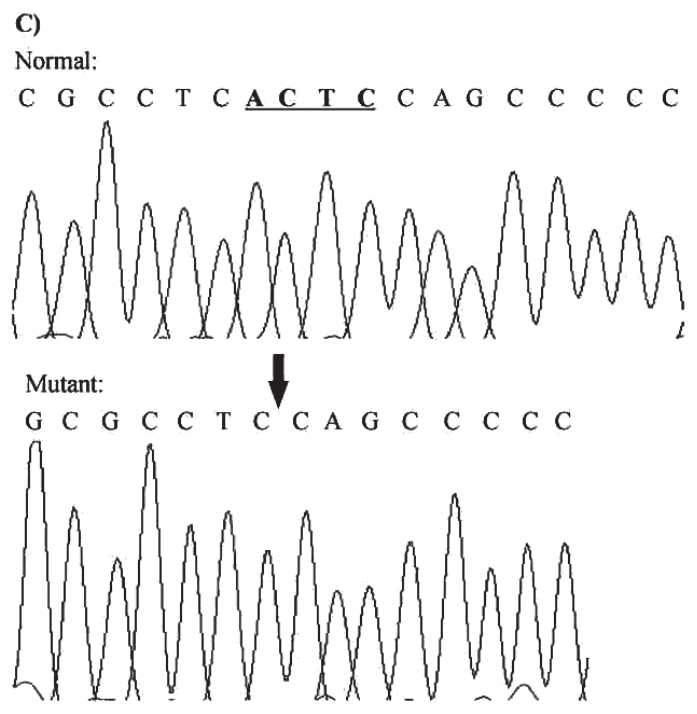

Figure 2. Sequence analysis showing the three novel mutations in the SLC7A9 genes. A) G73R; B) V375I; and C) 1048-1051delACTC in the homozygous state and a normal sequence of exon 10. 
type I cystinuria. Although G105R affects a highly conserved amino acid residue, a small percentage of the heterozygotes carrying this mutation exhibit elevated levels of urinary cystine and dibasic amino acids $[8,9,11]$.

A deletion of four nucleotides (ACTC) at position 1048-1051 in exon 10 in the SLC7A9 gene (Figure 2C) was detected in the homozygous state, in a Turkish patient (CY-36). This mutation was most probably generated by a mechanism of "slipped misspairing" between the two direct repeats (TC), followed by a deletion of one of the direct repeats and the intervening $\mathrm{AC}$ sequence [14]. Because of the urinary excretion profile of the parents, the patient was classified as non type I/non type I (Table 1). Consanguinity between the parents was confirmed.

In conclusion, this report describes two novel mutations in the SLC3A1 gene (C242R and L573X) and three in the SLC7A9 gene (G73R, V375I, 1048-1051delACTC) and expands the spectrum of cystinuria mutations.

\section{ACKNOWLEDGMENTS}

This study was supported by a grant No. 0959/1 from the Science Funds of the Macedonian Academy of Sciences and Arts, Skopje, Republic of Macedonia (to GDE).

\section{REFERENCES}

1. Segal S, Thier SO. Cystinuria. In: Scriver CR, Beaudet AL, Sly WS, eds: The Metabolic and Molecular Bases of Inherited Disease, 7th ed. New York: McGraw-Hill. 1995; 3581-3601.

2. Chillaron J, Roca R, Valencia A, Zorzano A, Palacin M. Heteromeric amino acid transporters: biochemistry, genetics, and physiology. Am J Physiol Renal Physiol 2001; 281(6): 995-1018.

3. Calonge MJ, Gasparini P, Chillaron J, Chillon M, Gallucci M, Rousaud F, Zelante L, Testar X, Dallapiccila B, Di Silverio F. Cystinuria caused by mutation in rBAT, a gene involved in the transport of cystine. Nat Genet 1994; 6(4): 420-425.

4. Bisceglia L, Calonge MJ, Totaro A, Feliubadalo L, Melchionda S, Garcia J, Testar X, Gallucci M, Ponzone A, Zelante L, Zorzano A, Estivill X, Gasparini P, Nunes V, Palacin M. Localization, by linkage analysis, of cystinuria type III gene to chromosome 19q13.1. Am J Hum Genet 1997; 60(3): 611-616.

5. Wartenfeld R, Golomb E, Katz G, Bale SJ, Goldman B, Pras M, Kastner DL, Pras E. Molecular analysis of cystinuria in Libyan Jews: exclusion of the SLC3A1 gene mapping of a new locus on 19q. Am J Hum Genet 1997; 60(3): 617-624.

6. Rosenberg L, Downing S, Durant JL, Segal S. Cystinuria: biochemical evidence for three genetically distinct diseases. J Clin Invest 1966; 45(3): 365371.

7. Feliubadalo L, Font M, Purroy J, Rousaud F, Estivill X, Nunes V, Golomb E, Centola M, Aksentijevich I, Kreiss Y, Goldman B, Pras M, Kastner DL, Pras E, Gasparini P, Bisceglia L, Beccia E, Gallucci M, de Sanctis L, Ponzone A, Rizzoni GF, Zelante L, Bassi MT, George AL Jr, Manzoni M, De Grandi A, Riboni M, Endsley JK, Ballabio A, Borsani G, Reig N, Fernandez E, Estevez R, Pineda M, Torrents D, Camps M, Lloberas J, Zorzano A, Palacin M, International Cystinuria Consortium. Non-type I cystinuria caused by mutations in SLC7A9, encoding a subunit (b0,+AT) of rBAT. Nat Genet 1999; 23(1): 52-57.

8. Dello Strologo L, Pras E, Pontesilli C, Beccia E, Ricci-Barbini V, de Sanctis L, Ponzone A, Gallucci M, Bisceglia L, Zelante L, Jimenez-Vidal M, Font M, Zorzano A, Rousaud F, Nunes V, Gasparini P, Palacin M, Rizzoni G. Comparison between SLC3A1 and SLC7A9 cystinuria patients and carriers: a need for a new classification. J Am Soc Nephrol 2002; 13(10): 2547-2553.

9. Font-Llitjos M, Jimenez-Vidal M, Bisceglia L, Di Perna M, de Sanctis L, Rousaud F, Zelante L, Palacin M, Nunes V. New insights into cystinuria: 40 new mutation, genotype-phenotype correlation, and digenic inheritance causing partial phenotype. J Med Genet 2005; 42(1): 58-68.

10. The Human Gene Mutation Database at the Institute of Medical Genetics in Cardiff (HGMD), 2008 (http:// www.hgmd.cf.ac.uk/ac/index.php).

11. Font MA, Feliubadalo L, Estivill X, Nunes V, Golomb E, Kreiss Y, Pras E, Bisceglia L, d'Adamo AP, Zelante L, Gasparini P, Bassi MT, George AL Jr, Manzoni M, Riboni M, Ballabio A, Borsani G, Reig N, Fernandez E, Zorzano A, Bertran J, Palacin M, International Cystinuria Consortium. Functional analysis of mutations in SLC7A9, and genotype-phenotype correlation in non-Type I cystinuria. Hum Mol Genet 2001; 10(4): 305-316. 
12. Bisceglia L, Calonge MJ, Dello Strologo L, Rizzoni G, de Sanctis L, Gallucci M, Beccia E, Testar X, Zorzano A, Estivill X, Zelante L, Palacin M, Gasparini $P$, Nunes V. Molecular analysis of the cystinuria disease gene: identification of four new mutations, one large deletion, and one polymorphism. Hum Genet 1996; 98(4): 447-451.

13. Saadi I, Chen XZ, Hediger M, Ong P, Pereira P, Goodyer P, Rozen R. Molecular genetics of cysti- nuria: mutation analysis of SLC3A1 evidence for another gene in type I (silent) phenotype. Kidney Int 1998; 54(1): 48-55.

14. Ball EV, Stenson PD, Abeysinghe SS, Krawczak M, Cooper DN, Chuzhanova NA. Microdeletions and microinsertions causing human genetic disease: common mechanisms of mutagenesis and the role of local DNA sequence complexity. Hum Mutat 2005; 26(3): 205-213. 